\title{
Determinan Kelemahan Pengendalian Intern Pemerintah Daerah Kabupaten/Kota Provinsi Jawa Timur
}

\author{
Tina Tuti Alawiyah, Mahendro Sumardjo, Dewi Darmastuti \\ Universitas Pembangunan Nasional Veteran Jakarta \\ Email: tina.alawiah@yahoo.com
}

Financial Internal

Control and

Government

415

Submitted:

SEPTEMBER 2020

Accepted: NOVEMBER 2020

\begin{abstract}
ABSTRAK
Penelitian ini bertujuan untuk mengetahui pengaruh ukuran pemerintah daerah, pendapatan asli daerah (PAD), belanja modal, dan jumlah penduduk pada kelemahan pengendalian intern di pemerintah daerah. Penelitian ini dilaksanakan dengan menggunakan analisis regresi linier berganda pada 104 sampel pemerintah daerah $\mathrm{kab} /$ kota pada provinsi jawa timur selama tahun 2016-2018, hasil penelitian menunjukkan bahwa tidak ada pengaruh yang signifikan terkait ukuran pemerintah daerah, belanja modal, dan jumlah penduduk pada kelemahan pengendalian intern di pemerintah daerah. Besar atau kecilnya ukuran pemerintah daerah, belanja modal, dan jumlah penduduk tidak bisa memastikan kelemahan pengendalian intern yang dimiliki pemerintah daerah menjadi sedikit atau banyak. Sedangkan PAD berpengaruh secara positif signifikan pada kelemahan pengendalian intern di pemerintah daerah. Besarnya PAD dapat berpotensi mendorong para pengelola dapat melakukan penyimpangan terhadap pengolaan keuangan daerah sehingga meningkatkan temuan kelemahan pengendalian intern pemerintah daerah.
\end{abstract}

Kata Kunci : ukuran pemerintah daerah; PAD; belanja modal; jumlah penduduk; kelemahan pengendalian intern.

\begin{abstract}
This study aims to determine the effect of local government size, local revenue (PAD), capital expenditure, and population on weaknesses in internal control in local governments. This research was carried out using multiple linear regression analysis on 104 samples of district / city governments in the province of East Java during 2016-2018, the results showed that there was no significant effect related to local government size, capital expenditure, and population on weakness in control. intern in local government. The size of the local government, the capital expenditure, and the population do not ensure that the internal control weaknesses owned by the regional government are small or large. Meanwhile, PAD has a significant positive effect on the weakness of internal control in local government. The amount of $P A D$ has the potential to encourage managers to commit irregularities in regional financial management, thereby increasing the findings of weaknesses in local government internal control.
\end{abstract}

Keywords: size of local government; PAD; capital expenditure; population; weaknesses of internal control.

\section{PENDAHULUAN}

Era Pemerintahan Indonesia pernah mengalami reformasi pada tahun 1998 dari sebelumnya yaitu era Orde Baru akibat adanya krisis kepercayaan masyarakat terhadap pemerintah karena seringkali tidak memihak kepentingan masyarakat (Dwiyanto, 2011). Pada masa orde baru, Indonesia menggunakan sistem pemerintahan terpusat (sentralisasi), namun pada masa tersebut pembangunan sentralisasi tidak berjalan

\section{JIAKES}

$$
\begin{array}{r}
\text { Jurnal Ilmiah Akuntansi } \\
\text { Kesatuan } \\
\text { Vol. } 8 \text { No. 3, 2020 } \\
\text { pg. 415-424 } \\
\text { IBI Kesatuan } \\
\text { ISSN 2337- } 7852 \\
\text { E-ISSN } 2721 \text { - 3048 }
\end{array}
$$


Financial Internal

Control and

Government

sesuai dengan semestinya, karena kegiatan dan infrastruktur yang dilakukan tidak diimbangi dengan pembentukan mental para pelaksana pemerintahan tersebut yang mendorong terjadinya kecurangan dan penyalahgunaan pemerintahan (Rahman, 2018). Sistem pemerintahan berubah menjadi desentralisasi dimana saat pemerintah daerah diberikan kewenangan untuk mampu menjalankan sendiri pemerintahan di daerahnya yang bertujuan agar bisa mengembangkan potensi daerahnya dan memberikan pelayanan dengan jarak lebih dekat terhadap masyarakat guna menciptakan kesejahteraan yang lebih merata kepada masyarakat. Munculnya masa desentralisasi mulai dilaksanakan dari UU No. 22 Tahun 1999 lalu diperbarui UU No. 23 Tahun 2014 Tentang Pemerintahan Daerah dimana adanya kebijakan dalam sistem pemerintahan daerah. Hal ini menjadikan suatu landasan dalam pemberian otonomi menjadi besar pada pemerintah daerah.

Besarnya otonomi daerah di Indonesia, membuat hal tersebut harus diiringi dengan pengawasan yang baik, Berdasarkan KPMG Fraud Survey 2006 ditemukan faktor utama penyebab terjadinya kecurangan yaitu akibat dari lemahnya pengendalian intern sebanyak 33\% dari total kasus kecurangan. Faktor kedua pada survey 2006 penyebab kecurangan adalah mengabaikan sistem pengendalian intern sebanyak $24 \%$ dari total kasus kecurangan. Hal tersebut menunjukkan bahwa adanya pengendalian intern dan implementasinya sangat penting untuk dilakukan (Martani \& Zaelani, 2011). Dalam PP 60 Tahun 2008 bahwa sistem pengendalian intern pemerintah agar tegas pada kebijakan pemerintah dalam mewujudkan tindakan untuk memberantas korupsi, kolusi, dan nepotisme pada pelaksananaan tugas di pemerintah, dimana tindakan tersebut harus dilakukan secara terus menerus pada semua pelaksana pemerintahan agar dapat terciptanya pengelolaan pada keuangan suatu negara dilakukan secara efektif, efisien, transparansi, dan juga akuntabel.

Berdasarkan ihtisar hasil dari pemeriksaan terhadap sistem pengendalian intern pada pemerintah daerah di Indonesia 2016-2018 membuktikkan masih banyaknya masalah kelemahan pada pengendalian intern yaitu 6150 kasus tahun 2016, 6.053 kasus pada tahun 2017, dan 6222 kasus pada tahun 2018. Temuan kelemahan yang meningkat pada pengendalian intern di lingkup pemerintah daerah dikarenakan masih tidak maksimalnya pengendalian intern di sektor pemerintah daerah. Permasalahan terkait dengan sistem pengendalian intern pemerintah di Jawa Timur pernah terjadi, dimana kinerja keuangannya menurun pada Pemerintah Provinsi Jawa Timur Tahun tahun 2014 dimana mendapatkan Wajar Dengan Pengecualian (WDP) dari sebelumnya Wajar Tanpa Pengecualian (WTP). Adanya penurunan opini tersebut karena ditemukannya beberapa temuan terhadap melemahnya sistem pengendalian intern di Pemerintah Provinsi Jawa Timur (Rois, 2015). Temuan pertama yaitu adanya kelemahan pengendalian kas, baik dari pengeluaran dan penerimaan yang dapat menyebabkan lebihnya pengeluaran kas dan adanya penerimaan kas yang tidak sah, hal ini bisa mengakibatkan ketidakwajaran akun kas, seperti di setiap SKPD adanya pembukaan rekening kas yang tidak tertib juga tidak sesuai pada ketentuan. Temuan yang kedua terkait realisasi pertanggungjawaban belanja barang dan jasa sebanyak Rp. 21,56 miliar di 23 SKPD tidak dapat menggambarkan keadaan yang sebenarnya. Anggaran sebanyak Rp. 31,45 miliar pada 10 SKPD belum didukung dengan lengkapnya bukti pertanggungjawaban. Apabila dihitung secara keseluruhan ada sekitar Rp. 53 miliar masih harus dibenahi dalam penggunaan anggaran (Hidayat \& Martudji, 2015). Banyaknya jumlah kelemahan pengendalian intern maka menunjukkan lemahnya sistem pengendalian intern pemerintah daerah, hal ini bisa menyebabkan peningkatan tingkat kecurangan bisa terjadi di organisasi/pemerintah.

Beberapa hasil penelitian sebelumnya Martani dan Zaelani (2011), Safitri dan Kiswanto (2019), Adha et al. 2019, Doyle et al. 2007 yang meneliti pengaruh ukuran suatu entitas atau pemerintah daerah pada kelemahan pengendalian intern menunjukkan bahwa adanya pengaruh signifikan negatif pada kelemahan pengendalian intern. Menurut Petrovits et al. (2011) menerangkan bahwa meningkatnya masalah pada pengendalian intern terjadi pada entitas yang ukurannya lebih kecil. Namun hasil 
penelitian itu tidak sesuai dengan penelitian Kristanto (2009) dan Iqbal (2017) dijelaskan ukuran pemerintah daerah berpengaruh positif signifikan pada kelemahan pengendalian intern. Adanya penelitian oleh Martani dan Zaelani (2011) dan Iqbal (2017) dimana meneliti pengaruh pendapatan asli daerah (PAD) terhadap kelemahan pengendalian intern menunjukkan adanya pengaruh positif signifikan pada kelemahan pengendalian intern berarti sumber pendapatan yang banyak dapat membuat masalah pengendalian intern menjadi meningkat. Hal ini berbeda dengan penelitian Aini (2017) dan Safitri dan Kiswanto (2019) menunjukkan adanya pengaruh negatif signifikan pada kelemahan pengendalian intern. Kristanto (2009) menunjukkan PAD mempunyai pengaruh yang negatif namun tidak signifikan pada kelemahan pengendalian intern.

Lalu pada penelitian Safitri dan Kiswanto (2019) serta Adha et al. (2019) yang meneliti pengaruh belanja modal terhadap kelemahan pengendalian internnya menunjukkan adanya pengaruh positif signifikan pada kelemahan pengendalian intern, namun tidak sesuai dengan penelitian Aini (2017), Iqbal (2017) dan Kristanto (2009) menunjukkan bahwa belanja modal tidak mempunyai pengaruh pada kelemahan pengendalian intern sebab naik atau turunnya belanja modal tidak dapat berpengaruh pada kelemahan pengendalian intern. Terkait jumlah penduduk pada kelemahan pengendalian intern pernah dilakukan pada Martani dan Zaelani (2011) dan Yamin dan Sutaryo (2015) bahwa adanya pengaruh yang negatif signifikan pada kelemahan pengendalian intern. Sedangkan menurut Iqbal (2017) jumlah penduduk berpengaruh dengan arah positif signifikan pada kelemahan pengendalian internnya. Berdasarkan hasil penelitian sebelumnya yang masih bervariasi/berbeda-beda, maka peneliti tertarik melakukan penelitian kembali mengenai kelemahan pengendalian intern di Pemerintah Daerah. Dimana yang membedakan dari penelitian sebelumnya bahwa penelitian ini memodifikasi pengukuran terdahulu dari adanya penelitian Kristanto (2009) yang mengukur ukuran pemerintah daerah menggunakan jumlah pendapatan daerah, sedangkan pada penelitian Safitri dan Kiswanto (2019) menggunakan jumlah SKPD yang diharapkan untuk menggunakan variabel terkait aset, sehingga peneliti akan memodifikasi pengukuran pada variabel ukuran pemerintah daerah menggunakan aset dan peneliti akan berfokus mengambil sampel data Pemerintah Daerah di KabupatenKota yang ada di Jawa Timur periode 2016-2018.

Hal ini bertujuan untuk menganalisis pengaruh ukuran pemerintah daerah, PAD, belanja modal, jumlah penduduk terhadap kelemahan pengendalian intern pemerintah daerah dan perkembangan pengendalian intern di daerah Jawa Timur. Penelitian ini diharapkan bisa memberikan informasi mengenai hal-hal yang dapat membuat lemahnya pengendalian intern terjadi pada lingkup pemerintah daerah dan pentingnya penerapan pengendalian intern yang baik dalam pemerintah daerah. Diharapkan bisa sebagai masukan agar lebih menegaskan kebijakan dalam pentingnya meningkatkan pengendalian intern, guna untuk mengurangi tindakan kecurangan yang dapat terjadi di pemerintah daerah, sehingga dapat terciptanya pengelolaan keuangan yang baik dan bisa memaksimalkan potensi daerah untuk mensejahterakan rakyat dan mampu meningkatkan kemajuan daerah tersebut.

\section{Pengembangan Hipotesis}

Ukuran pemerintah daerah merupakan skala yang bisa mengukur besar kecilnya suatu entitas/pemeritah daerah. Menurut Adha et al. (2019) ukuran entitas mempunyai pengaruh secara negatif pada kelemahan pengendalian intern karena besarnya ukuran pemerintah daerah dapat mendorong implementasi sistem pengendalian intern yang lebih baik sebagai pertanggungjawaban agen pada prinsipal untuk dapat menjaga keutuhan aset aset yang berada dalam pengelolaannya. Sumber daya yang besar membuat implementasi sistem pengendalian intern dapat berjalan dengan baik karena dapat menerapkan tertib administrasi dan pengelolaan keuangan daerah dimana adanya pembagian tanggung jawab yang lebih teratur dalam pengelolaannya didukung oleh Martani dan Zaelani (2011). Penelitian Safitri dan Kiswanto (2019) menunjukkan besarnya ukuran pemerintah daerah mempunyai pengaruh secara negatif pada kelemahan pengendalian intern di pemerintah daerah karena adanya tugas dan
Financial Internal Control and Government 
Financial Internal Control and

Government

\section{8}

tanggung jawab yang lebih memadai dan teratur dalam memberikan pelayanan terhadap masyarakat. Menurut Doyle et al. (2007) umumnya kelemahan pengendalian intern terdapat pada entitas kecil. Pada penelitian Petrovits et al. (2011) meningkatnya permasalahan pada pengendalian intern terjadi pada entitas yang lebih kecil ukuran total asetnya. Berdasarkan uraian tersebut maka dapat dirumuskan hipotesis yaitu:

$\mathrm{H}_{1}$ : Ukuran Pemerintah Daerah berpengaruh negatif terhadap Kelemahan

Pengendalian Intern Pemerintah Daerah.

PAD ialah pendapatan daerah yang berasal dari daerahnya sendiri didapatkan dari mengelola dan memanfaatkan potensi pada daerahnya sesuai dengan kemampuan yang dimiliki daerah tersebut dimana PAD mempunyai pengaruh negatif pada kelemahan pengendalian intern maka berarti tingginya $\mathrm{PAD}$ memungkinkan pengendalian intern nya dapat berjalan secara lebih baik (Safitri \& Kiswanto, 2019). Dilihat dari adanya kemampuan finansial pemerintah daerah yang tinggi dapat melakukan alokasi dana lebih besar bagi kegiatan implementasi pengendalian intern yang memadai agar bisa menurunkan terjadinya tindak kecurangan. Menurut Kristanto (2009) PAD mempunyai peran penting mengenai biaya pengeluaran atau belanja daerah karena pendapatan ini merupakan hasil dari pengelolaan daerah sendiri yang dapat digunakan sepenuhnya untuk pembangunan daerah. Sejalan dengan Aini (2017) bahwa tingginya PAD membuat pemerintah dapat bekerja semaksimal mungkin untuk melaksanakan pengendalian intern yang efektif untuk bisa melindungi pos-pos penerimaan daerahnya. Adanya uraian tersebut maka bisa dirumuskan hipotesis yaitu:

$\mathrm{H}_{2}$ : Pendapatan Asli Daerah (PAD) berpengaruh negatif terhadap Kelemahan

Pengendalian Intern Pemerintah Daerah.

Pada PP No. 71 Tahun 2010 yang dimaksud belanja modal ialah belanja yang dilaksanakan terkait pengadaan aset tetap dengan masa manfaatnya bisa melebihi 1 tahun anggaran dan dimaksudkan menambahkan aset atau kekayaan pada daerah dan memberikan pelayanan kepada masyarakat. Menurut Safitri dan Kiswanto (2019) banyaknya proyek belanja modal yang dilaksanakan pada pengadaan aset tetapnya berpengaruh positif pada kelemahan pengendalian intern di pemerintah daerah karena bisa sangat rawan terjadinya kecurangan dalam proses pengadaannya. Didukung juga oleh Adha et al. (2019) bahwa anggaran belanja mempunyai pengaruh positif pada kelemahan SPI, semakin banyaknya anggaran belanja bisa timbul adanya kondisi dimana pemerintah daerah melakukan kesalahan pengalokasian anggaran belanja modalnya sehingga meningkatkan kelemahan pengendalian internnya. Sehingga dari uraian tersebut bisa dirumuskan hipotesisnya yaitu:

$\mathrm{H}_{3}$ : Belanja Modal berpengaruh positif terhadap Kelemahan Pengendalian Intern Pemerintah Daerah.

Penduduk berperan sebagai stakeholders bagi instansi pemerintah yang dapat membuat tekanan kepada pihak pemerintah agar terdorongnya transparansi terkait informasi atas pengelolaan keuangan daerahnya dengan sistem pengendalian intern yang memadai sebagai bentuk pertanggungjawabannya kepada publik dimana jumlah penduduk berpengaruh negatif pada kelemahan pengendalian intern pemerintah daerah (Yamin \& Sutaryo, 2015). Menurut Martani dan Zaelani (2011) bahwa jumlah penduduk mempunyai pengaruh secara negatif pada kelemahan pengendalian intern dimana banyaknya jumlah penduduk bisa membuat pengendalian intern pada pemerintah daerah bisa meningkat disebabkan meningkatnya tuntutan dalam pengungkapan laporan. Adanya uraian tersebut maka bisa dirumuskan hipotesisnya yaitu: $\mathrm{H}_{4}$ : Jumlah Penduduk berpengaruh negatif terhadap Kelemahan Pengendalian Intern Pemerintah Daerah.

\section{METODE PENELITIAN}

Populasi yang menjadi objek penelitian ini yaitu seluruh pemerintah daerah kabupaten/kota di Provinsi Jawa Timur berjumlah 39 tahun 2016, 2017, 2018 sehingga populasi berjumlah 117. Teknik pengambilan sampel yang digunakan pada penelitian ini adalah teknik sampling jenuh atau disebut sensus sampling dimana saat semua 
anggota pada populasi dijadikan sebagai sampel sehingga menjadi 117 data (Sugiyono, 2017, hlm.85). Data pada penelitian ini ialah data yang bersumber dari Laporan Hasil Pemeriksaan (LHP) BPK atas LKPD (Laporan Keuangan Pemerintah Daerah) yaitu pada ukuran pemerintah daerah berdasarkan total asetnya, dan PAD dengan melihat total PAD dan total keseluruhan pendapatan daerah serta belanja modal berdasarkan total realisasi belanja modal daerah. Lalu kelemahan pengendalian intern melihat dari jumlah temuan kelemahan yang bersumber dari LHP atas Sistem Pengendalian Intern (SPI) yang juga didukung dengan tabel jumlah kelemahan Sistem Pengendalian Intern pada IHPS BPK serta jumlah penduduk yang bersumber pada Badan Pusat Statistik (BPS). Metode penelitian ini adalah kuantitatif dengan uji hipotesis melalui uji t dan uji $\mathrm{R}^{2}$ menggunakan bantuan program olah data SPSS 25 . Pada penelitian menggunakan analisis regresi linear berganda dan sebelum melakukan uji hipotesis, data perlu memenuhi uji asumsi klasik terlebih dahulu yaitu memenuhi atas uji multikolonieritas, uji heteroskedastisitas, dan uji normalitas lalu data tersebut akan dianalisa melalui statistik deskriptif bertujuan agar dapat melihat gambaran secara umum. Adapun model regresinya yaitu:

Keterangan:

$$
Y_{K P I}=\alpha+\beta_{1} X_{1}+\beta_{2} X_{2}+\beta_{3} X_{3}+\beta_{4} X_{4}+\varepsilon
$$

YKPI = Kelemahan pengendalian intern

$\alpha \quad=$ Konstanta (tetap)

$\beta=$ Koefisien Regresi

$\mathrm{X} 1=$ Ukuran Pemerintah Daerah

$\mathrm{X} 2$ = Pendapatan Asli Daerah (PAD)

$\mathrm{X} 3$ = Belanja Modal

X4 = Jumlah Penduduk

$\varepsilon \quad=$ Error

\section{HASIL DAN PEMBAHASAN}

Tabel 1. Pembagian Sampel

\begin{tabular}{llc}
\hline No. & \multicolumn{1}{c}{ Keterangan } & Sampel \\
\hline 1 & $\begin{array}{l}\text { Pemerintah daerah Kabupaten dan Kota di Provinsi Jawa } \\
\text { Timur 2016-2018 }\end{array}$ & 39 \\
\hline 2 & $\begin{array}{l}\text { Jumlah pemerintah daerah Kabupaten dan Kota di Provinsi } \\
\text { Jawa Timur yang tidak menyusun Laporan Keuangan }\end{array}$ & - \\
& \begin{tabular}{l} 
Pemerintah Daerah (LKPD) atau belum diperiksa BPK \\
\hline 3
\end{tabular} & $\begin{array}{l}\text { Jumlah pemerintah daerah Kabupaten dan Kota di Provinsi } \\
\text { Jawa Timur yang tidak dilakukan pemeriksaan atas sistem } \\
\text { pengendalian intern oleh BPK }\end{array}$ \\
\hline 4 & $\begin{array}{l}\text { Jumlah pemerintah daerah Kabupaten dan Kota di Provinsi } \\
\text { Jawa Timur yang tidak memiliki data kependudukan pada }\end{array}$ & - \\
\hline & Badan Pusat Statistik & 3 \\
\hline & Jumlah tahun penelitian & 117 \\
\hline & Jumlah data sebelum outlier & $(13)$ \\
\hline & Jumlah data yang di outlier & 104 \\
\hline
\end{tabular}

Sumber: Data diolah oleh Peneliti

Penelitian ini telah memenuhi semua uji asumsi klasik, namun setelah melakukan pengujian pada normalitas terdapat beberapa data yang bernilai ekstrim sehingga dengan beberapa pertimbangan dilakukannya outlier sebanyak 13 data, maka data yang dijadikan sampel menjadi 104 data penelitian.

Berdasarkan data sebelum outlier menunjukkan ukuran pemerintah daerah memiliki nilai terkecil pada Kabupaten Sumenep tahun 2017 dan terbesarnya pada Kota Surabaya tahun 2018. Pendapatan Asli Daerah (PAD) mempunyai nilai terkecil dimiliki oleh Kabupaten Sampang tahun 2016 dan terbesarnya dimiliki oleh Kota Surabaya
Financial Internal Control and Government 
Financial Internal Control and Government tahun 2017. Belanja modal mempunyai nilai terkecil yang dimiliki oleh Kota Mojokerto tahun 2018 dan terbesarnya pada Provinsi Jawa Timur tahun 2017. Jumlah penduduk memiliki nilai terkecil berada di Kota Mojokerto tahun 2016 dan terbesar ada di Provinsi Jawa Timur tahun 2018. Variabel dependen (terikat) yaitu kelemahan pengendalian intern menunjukkan jumlah temuan terkecil pada Kabupaten Banyuwangi tahun 2018 dan terbanyak dimiliki oleh Kota Surabaya tahun 2017.

Tabel 2. Statistik Deskriptif

\begin{tabular}{|c|c|c|c|c|c|}
\hline Variabel & $\mathbf{N}$ & Minimum & Maximum & Mean & $\begin{array}{l}\text { Std. } \\
\text { Deviation }\end{array}$ \\
\hline SIZE & 117 & 26.893 & 31.387 & 28.92714 & 0.734842 \\
\hline PAD & 117 & 0.079 & 0.643 & 0.18734 & 0.116661 \\
\hline Belanja Modal & 117 & 25.506 & 28.759 & 26.71359 & 0.619837 \\
\hline Penduduk & 117 & 11.747 & 17.492 & 13.69964 & 0.997149 \\
\hline KPI & 117 & 2 & 22 & 9.56 & 3.962 \\
\hline Valid N (listwise) & 117 & & & & \\
\hline \multicolumn{6}{|c|}{$\begin{array}{l}\text { Sumber: Data diolah oleh Peneliti } \\
\text { Tabel 3. Hasil Uji T }\end{array}$} \\
\hline & B & & $\mathbf{t}$ & Sig. & \\
\hline (Constant) & 57.375 & & 2.166 & 0.033 & \\
\hline SIZE & -1.573 & & -1.585 & 0.116 & \\
\hline PAD & 13.201 & & 2.647 & 0.009 & \\
\hline Belanja Modal & -0.436 & & -0.385 & 0.701 & \\
\hline Penduduk & 0.447 & & 0.714 & 0.477 & \\
\hline
\end{tabular}

Sumber : Data diolah oleh Peneliti

Nilai t hitung pada ukuran pemerintah daerah adalah senilai -1.585 dimana nilai t hitungnya lebih kecil daripada t tabelnya yaitu 1.984 dan nilai signifikansi senilai 0.116 maka lebih besar dari nilai 0.05 atau 5\%. Sehingga menunjukkan bahwa diterimanya Ho1 dan Ha1 nya ditolak karena secara parsial ukuran pemerintah daerah tidak mempunyai pengaruh signifikan pada kelemahan pengendalian intern.

Hasil uji statistik $t$ diatas bahwa nilai $t$ hitung pada PAD sebesar 2.647 dimana memiliki nilai $\mathrm{t}$ hitung yang lebih besar daripada $\mathrm{t}$ tabelnya yaitu 1.984 dengan nilai signifikansi senilai 0.009 maka nilainya lebih kecil dari 0.05 atau 5\%. Hal ini menunjukkan bahwa ditolaknya Ho2 dan penerimaan Ha2 sebab secara parsial PAD mempunyai pengaruh signifikan pada kelemahan pengendalian intern dengan koefisiennya yang menunjukkan arah positif.

Adapun nilai t hitung pada belanja modal sebesar -0.385 yang berarti bahwa nilai t hitungnya lebih kecil daripada $t$ tabelnya yaitu 1.984 beserta nilai signifikansinya sebesar 0.701 maka menunjukkan nilai yang lebih besar dari nilai 0.05 atau 5\%. Hal ini berarti Ho3 nya diterima dan $\mathrm{Ha} 3$ nya ditolak karena secara parsial belanja modal tidak mempunyai pengaruh signifikan pada kelemahan pengendalian intern.

Dilihat bahwa nilai t hitung pada jumlah penduduk ialah sebesar 0.714 memiliki nilai $t$ hitung yang lebih kecil daripada $t$ tabelnya yaitu 1.984 beserta nilai signifikansinya sebesar 0.477 yang lebih besar dari nilai 0.05 atau $5 \%$. Hasilnya menunjukkan diterima nya Ho4 dan $\mathrm{Ha} 4$ yang ditolak sebab secara parsial jumlah penduduk tidak berpengaruh signifikan pada kelemahan pengendalian intern.

Tabel 4. Uji Koefisien Determinasi $\left(\mathrm{R}^{2}\right)$

\begin{tabular}{cccc}
\hline $\mathbf{R}$ & R Square & Adjusted R Square & Std. Error of the Estimate \\
\hline 0.265 & 0.070 & 0.033 & 3.146 \\
\hline
\end{tabular}

Sumber : Data diolah oleh Peneliti

Pada tabel uji $\mathrm{R}^{2}$ menunjukkan nilai dari adjusted $\mathrm{R}$ Square senilai 0.033 atau 3.3\% berarti variabel kelemahan pengendalian intern bisa dijelaskan melalui variabel ukuran pemerintah daerah, PAD, belanja modal, dan jumlah penduduk sebesar 3.3\% dari $100 \%$ sedangkan sisa nya sebesar $96.7 \%$ dijelaskan melalui faktor faktor lain diluar penelitian ini. 
Hasil penelitian tersebut menerangkan besarnya ukuran pemerintah daerah tidak dapat dijadikan dasar pada sedikit atau banyaknya temuan kelemahan pengendalian intern karena pada dasarnya adanya kelemahan pengendalian intern disebabkan tidak berjalannya sistem pengendalian intern yang baik dan sangat bergantung pada keefektifan pelaksanannya bukan dari banyaknya aset atau sumber daya yang mendukung dalam kegiatan pengendalian internnya. Jumlah aset besar belum bisa menjamin sistem pengendalian internnya bisa lebih baik daripada pemerintah daerah yang mempunyai jumlah aset sedikit, mengingat kecilnya ukuran pemerintah dapat menjadikan ruang lingkup pengendalian menjadi kecil sehingga lebih mudah dilakukan pengawasan atau dijalankannya pengendalian intern yang lebih baik.

Hal ini dibuktikkan pada Kota Probolinggo tahun 2017 merupakan pemerintah daerah yang termasuk berukuran kecil dengan nilai 28.096 atau memiliki total aset sebesar Rp. 1,592,418,090,129.47 dengan 4 temuan kelemahan pengendalian internnya. Lalu dibuktikkan juga pada Kota Mojokerto tahun 2018 dengan ukuran pemerintah daerah bernilai 28.249 atau memiliki total aset yang kecil sebesar Rp. 1,854,530,373,707.83 dengan 4 temuan kelemahan pengendalian intern. Penelitian ini tidak sejalan dengan Martani dan Zaelani (2011), Adha et al. (2019), dan Safitri dan Kiswanto (2019) bahwa ukuran pemerintah daerah berpengaruh signifikan negatif pada kelemahan pengendalian intern pemerintah daerah. Pada teori keagenan yaitu pemerintah daerah sebagai pihak agen dituntut terkait tanggung jawabnya dalam pengelolaan daerah, adanya wewenang yang besar terhadap pengelolaan daerah juga perlu didukung dengan adanya pengendalian intern yang baik pula dalam kegiatan pengelolaannya, banyaknya aset dapat mendukung kegiatan pengendalian intern lebih memadai namun bila tidak adanya keefektifan dalam pelaksanan pengendalian internnya menjadikan besar atau kecilnya pemerintah tidak dapat mempengaruhi temuan kelemahan pengendalian intern di pemerintah daerah.

\section{Pendapatan Asli Daerah (PAD) terhadap Kelemahan Pengendalian Intern Pemerintah Daerah}

Hasil penelitian menerangkan semakin besarnya PAD di pemerintah daerah bisa membuat masalah kelemahan pengendalian intern semakin banyak. Timbulnya banyak kasus kelemahan pengendalian intern pemerintah daerah bisa disebabkan karena besarnya PAD yang masuk sebab dapat berpotensi mendorong para pengelola melakukan penyimpangan terhadap pengolaan keuangan daerah yang membuat jumlah temuan kelemahan pengendalian intern di pemerintah daerah semakin meningkat.

Dibuktikkan pada pemerintah Provinsi Jawa Timur tahun 2016 yang memiliki tingkat PAD besar dengan nilai 0.634 atau memiliki total PAD sebesar Rp. 15,817,795,024,796.9 atas keseluruhan pendapatan sebesar Rp. 24,962,122,477,069.5 dengan 17 temuan kelemahan pengendalian intern nya. Lalu Kota Surabaya tahun 2018 yang memiliki tingkat PAD besar senilai 0.608 atau memiliki total PAD sebesar 4,973,031,004,727.1 atas jumlah keseluruhan pendapatan sebesar Rp. $8,175,219,120,669.1$ dengan 12 jumlah temuan kelemahan pengendalian intern. Penelitian ini sejalan dengan Iqbal (2017) dan Martani dan Zaelani (2011) bahwa PAD mempunyai pengaruh secara positif pada kelemahan pengendalian intern pemerintah daerah. Namun hal ini tidak sejalan dengan Aini (2017) dan Safitri dan Kiswanto (2019) bahwa PAD mempunyai pengaruh secara negatif pada kelemahan pengendalian intern. Hal ini pun tidak sejalan dengan penelitian Kristanto (2009) dimana PAD mempunyai pengaruh secara negatif namun tidak signifikan pada kelemahan pengendalian intern. Dalam teori keagenan pihak agen atau pemerintah daerah telah diberikan kepercayaan oleh prinsipal untuk dapat mengelola daerah dengan baik, namun sebagai pihak pengelola daerah mereka dapat memanfaatkan posisinya tersebut untuk kepentingan pribadi atau tidak mementingkan kepentingan prinsipal/masyarakat, apalagi bila 
Financial Internal Control and Government

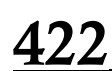

adanya pendapatan yang besar cenderung dapat terjadinya penyelewangan sehingga dapat meningkatkan kasus kelemahan pengendalian intern pada pemerintah daerah.

\section{Belanja Modal terhadap Kelemahan Pengendalian Intern Pemerintah Daerah}

Hasil penelitian tersebut menunjukkan bahwa besarnya belanja modal tidak dapat mempengaruhi temuan kelemahan pengendalian intern. Pada teori keagenan, pihak agen atau pemerintah daerah bertanggung jawab atas pengelolaan daerah untuk meningkatkan pelayanan kepada pihak prinsipal/masyarakat salah satunya melalui adanya kegiatan pengadaan aset tetap namun hasil penelitian ini menunjukkan belanja modal tidak dapat mempengaruhi jumlah permasalahan pada kelemahan pengendalian intern. Terdapat faktor lain diantaranya karena kurangnya kepedulian masyarakat atas pengadaan aset tetap yang telah dilakukan pemerintah daerah membuat pemerintah daerah bisa saja menjadi mengabaikan transparansi dan akuntabilitas atas pengelolaan keuangan daerah sehingga saat adanya kelemahan pada alokasi belanja modal menjadi seolah tidak terlihat. Hal ini dapat membuat pemerintah daerah akan mengesampingkan melakukan pengelolaan keuangan daerah yang baik sesuai dengan semestinya.

Hal ini dibuktikkan pada Kabupaten Banyuwangi tahun 2016 yang memiliki realisasi belanja modal besar dengan nilai 27.538 atau memiliki total belanja modal sebesar $\mathrm{Rp}$. 911,584,332,145.43 dengan 4 temuan kelemahan pengendalian intern. Adapun belanja modal yang kecil juga dapat memiliki jumlah temuan pada kelemahan pengendalian intern yang sedikit dibuktikannya pada Kota Mojokerto tahun 2018 yang memiliki realisasi belanja modal paling kecil dengan nilai 25.506 atau memiliki total belanja modal sebesar Rp. 119,434,272,446.86 dengan 4 temuan kelemahan pengendalian intern nya. Penelitian ini sejalan dengan Kristanto (2009), Aini (2017), Iqbal (2017) dimana belanja modal tidak mempunyai pengaruh signifikan pada kelemahan pengendalian intern pemerintah daerah. Penelitian ini tidak sejalan dengan Adha et al. (2019) dan Safitri dan Kiswanto (2019) belanja modal mempunyai pengaruh signifikan positif pada kelemahan pengendalian intern pemerintah daerah.

\section{Jumlah Penduduk terhadap Kelemahan Pengendalian Intern Pemerintah Daerah}

Hasil penelitian menunjukkan jumlah penduduk tidak dapat dijadikan dasar pada sedikit atau banyaknya temuan kelemahan pengendalian intern. Penduduk yang besar memang dapat meningkatkan sikap tanggung jawab pemerintah daerah untuk melakukan pengelolaan yang baik karena meningkatnya tuntutan publik atau banyaknya sorotan terhadap pemerintah daerah. Namun penduduk yang sedikit juga belum tentu akan menghasilkan banyaknya temuan kelemahan pengendalian intern karena tergantung pada sikap personal atau kesadaran para pihak agen untuk dapat mengelola dengan baik atau tidak dan tingkat kepedulian penduduk yang besar dalam memperhatikan pengelolaan pihak agen.

Hal ini dibuktikkan pada Kota Mojokerto tahun 2018 yang memiliki jumlah penduduk sedikit dengan nilai 11.762 atau memiliki total penduduk sebesar 128,282 jiwa beserta 4 temuan kelemahan pengendalian internnya. Lalu dibuktikkan juga pada Kota Probolinggo tahun 2017 yang memiliki penduduk sedikit dengan nilai 12.359 atau memiliki total penduduk sebesar 233,123 jiwa dengan 4 temuan kelemahan pengendalian intern yang kecil. Penelitian ini tidak sejalan dengan Martani dan Zaelani (2011) dan Yamin dan Sutaryo (2015) yang menunjukkan bahwa jumlah penduduk mempunyai pengaruh signifikan negatif pada jumlah temuan kelemahan pengendalian intern. Pada teori keagenan pemerintah daerah diberikan wewenang untuk mengelola daerahnya dengan baik untuk kepentingan masyarakat. Hasil penelitian ini menunjukkan bahwa banyaknya masyarakat atau penduduk tidak menjamin membuat pemerintah daerah terdorong untuk melakukan pengelolaan daerah yang baik. Terdapat faktor lain yaitu karena masih rendahnya kepedulian penduduk terhadap kinerja pengelolaan daerah membuat pemerintah daerah menjadi tidak tertekan untuk meningkatkan kinerja pengelolaan daerahnya dan masih kurangnya pembentukan sikap yang baik pada pihak pengelola sehingga menjadikan masih rendahnya kesadaran pemerintah daerah untuk bisa mengelola dengan baik daerahnya. 


\section{PENUTUP}

Ukuran pemerintah daerah tidak mempunyai pengaruh signifikan pada kelemahan pengendalian intern pemerintah daerah. Ukuran suatu pemerintah daerah tidak bisa memastikan kelemahan pengendalian intern yang dimiliki pemerintah daerah menjadi sedikit atau banyak. Kelemahan pengendalian intern pada dasarnya disebabkan karena tidak berjalannya sistem pengendalian intern yang baik dan sangat bergantung pada keefektifan pelaksanannya bukan karena banyaknya aset atau sumber daya dalam kegiatan pengendalian internnya. Sedangkan PAD mempunyai pengaruh signifikan positif pada kelemahan pengendalian intern di pemerintah daerah. Besarnya PAD dapat berpotensi mendorong para pengelola dapat melakukan penyimpangan terhadap pengolaan keuangan daerah sehingga membuat sistem pengendalian intern tidak berjalan dengan baik yang membuat jumlah temuan kelemahan pengendalian intern di pemerintah daerah semakin meningkat. Adapun belanja modal tidak mempunyai pengaruh pada kelemahan pengendalian intern pemerintah daerah. Besar atau kecilnya belanja modal terlihat menjadi seolah tidak mempengaruhi jumlah dari kelemahan pengendalian intern dikarenakan tingkat kepedulian masyarakatnya rendah atas informasi pengalokasian belanja modal sehingga membuat pemerintah dapat mengesampingkan transparansi dan akuntabilitasnya atas pengelolaan keuangan daerahnya sehingga saat adanya kelemahan pengendalian intern pada alokasi belanja modal menjadi seolah tidak terlihat. Sama halnya dengan jumlah penduduk tidak ada pengaruh pada kelemahan pengendalian intern dalam pemerintah daerah. Dimana tergantung pada sikap personal atau kesadaran para pihak agen untuk dapat mengelola dengan baik atau tidak dan tingkat kepedulian penduduk yang besar dalam memperhatikan pengelolaan pihak agen.

Analisis penelitian ini belum bisa disebut sempurna dan masih adanya keterbatasan yaitu data penelitian hanya berdasarkan 1 provinsi saja yaitu Provinsi Jawa Timur sehingga hasilnya bisa saja tidak menggambarkan secara umum untuk dipakai di seluruh Indonesia. Adapun saran bagi peneliti selanjutnya diharapkan bisa menambah variabel lainnya yang bisa mempunyai pengaruh pada kelemahan pengendalian intern di pemerintah daerah seperti belanja operasional dan pendapatan dari Pemerintah Pusat (DAU) dan menambah sampel yang lebih luas agar dapat menggambarkan hasil penelitian secara umum. Bagi pemerintah daerah diharapkan dapat meningkatkan keefektifan pelaksanaan pengendalian intern di pemerintah daerah sehingga bisa mengurangi jumlah temuan kelemahan pengendalian internnya. Hal tersebut juga perlu didukung dengan meningkatkan sikap personal atau kesadaran pemerintah daerah atas kepatuhan terhadap aturan dalam pengelolaan daerahnya agar terciptanya pengelolaan dan pelaporan keuangan daerah yang baik serta meningkatkan pemantauan pengendalian untuk mencegah terjadinya penyelewengan.

\section{DAFTAR PUSTAKA}

Adha, A. F., Afiah, N. N., \& Pratama, A. 2019. Pengaruh Ukuran Entitas Dan Kompleksitas Terhadap Kelemahan Pengendalian Intern Pada Kementerian PUPR. Jurnal SIKAP (Sistem Informasi, Keuangan, Auditing Dan Perpajakan), 3(2), $122-134$.

Aini, F. 2017. Pengaruh Pertumbuhan Ekonomi, Pendapatan Asli Daerah (PAD), Kompleksitas Daerah dan Belanja Modal Terhadap Kelemahan Pengendalian Intern Pemerintah Daerah. JOM Fekon, 4(1), 777-789.

Arens, A. A., Elder, R. J., \& Beasley, M. S. 2014. Auditing and Assurance Service yang diterjemahkan menjadi Auditing \& Jasa Assurance: Pendekatan Terintegrasi Edisi Kelima Belas Buku 1. Erlangga: Jakarta.

Aswar, K. 2019. Financial Performance of Local Governments in Indonesia. European Journal of Business and Management Research, 4(6), 1-6.

BPK. 2017. Ikhtisar Hasil Pemeriksaan Semester I Tahun 2017. Diakses pada 27 Februari 2020, dari https://www.bpk.go.id/ihps/2017/I. 
Financial Internal Control and

Government
Doyle, J., Ge, W., \& McVay, S. 2007. Determinants of weaknesses in internal control over financial reporting. Journal of Accounting and Economics, 44(1-2), 193-223.

Dwiyanto, A. 2011. Mengembalikan Kepercayaan Publik Melalui Reformasi Birokrasi. Gramedia: Jakarta.

Hayes, R., Wallage, P., \& Gortemaker, H. 2017. Principles of Auditing yang diterjemahkan menjadi Prinsip-Prinsip Pengauditan. Salemba Empat: Jakarta.

Hidayat, M. A., \& Martudji, T. 2015. BPK Temukan Kelemahan Pengendalian Kas Pemprov Jatim. Diakses 8 Maret 2019, dari https://m.viva.co.id/amp/berita/nasional/640130-bpk-temukan-kelemahanpengendalian-kas-pemprov-jatim?espv $=1$.

Iqbal, M. 2017. Pengaruh Tingkat Pertumbuhan Ekonomi, Pendapatan Asli Daerah, Ukuran Pemerintah Daerah, Belanja Modal, Dan Jumlah Penduduk Terhadap Kelemahan Pengendalian Intern Pada Pemerintah Daerah. JOM Fekon, 4(1), 881895.

Kristanto. 2009. Pengaruh Ukuran Pemerintahan, Pendapatan Asli Kelemahan Pengendalian Internal. Jurnal Akuntansi UKRIDA, 9(1), 1-17.

Martani, D., \& Zaelani, F. 2011. Pengaruh ukuran, pertumbuhan, dan kompleksitas terhadap pengendalian intern pemerintah daerah studi kasus di indonesia. Simposium Nasional Akuntansi XIV Aceh 2011, 1-27.

Patarai, M. I. 2016. Perencanaan Pembangunan Daerah (Sebuah Pengantar). De La Macca: Makassar.

Peraturan Menteri Keuangan Nomor 101/PMK.02/2011 Tentang Klasifikasi Anggaran.

Peraturan Pemerintah RI Nomor 71 Tahun 2010 Tentang Standar Akuntansi Pemerintahan.

Peraturan Pemerintah No. 60 Tahun 2008 Tentang Sistem Pengendalian Intern Pemerintah.

Petrovits, C., Shakespeare, C., \& Shih, A. 2011. The causes and consequences of internal control problems in nonprofit organizations. The Accounting Review, 86(1), $325-357$.

Rahman, F. 2018. Teori Pemerintahan. UB Press: Malang.

Rai, I. G. A. 2008. Audit Kinerja pada Sektor Publik. Salemba Empat: Jakarta.

Rois, J. 2015. BPK Nilai Sistem Pengendalian Intern Pemprov Jatim Lemah. Diakses pada 8 Maret 2019, dari https://m.detik.com/news/berita-jawa-timur/d-2955206/bpknilai-sistem-pengendalian-intern-pemprov-jatim-lemah

Safitri, S.A ., \& Kiswanto. 2019. Pertumbuhan Ekonomi Memoderasi Determinan Kelemahan Pengendalian Internal Pemerintah Daerah. Equilibria Pendidikan, 4(1), $1-9$.

Saputro, E. A., \& Mahmud, A. 2015. Analisis Faktor-Faktor yang Berpengaruh Terhadap Kelemahan Pengendalian Intern Pemerintah Daerah. Accounting Analysis Journal, 4(3), 1-9.

Sugiyono. 2017. Metode Penelitian Kuantitatif, Kualitatif, Dan R\&D. Alfabeta: Bandung.

Undang-Undang Nomor 12 Tahun 2006 Tentang Kewarganegaraan Republik Indonesia.

Undang-Undang Nomor 22 Tahun 1999 Tentang Pemerintahan Daerah.

Undang-Undang Nomor 23 Tahun 2014 Tentang Pemerintahan Daerah.

Undang-Undang Nomor 33 tahun 2004 Tentang Perimbangan Keuangan Antara Pemerintah Pusat Dan Pemerintah Daerah.

Yamin, R., \& Sutaryo. (2015). Faktor Penentu Jumlah Temuan Kelemahan Sistem Pengendalian Intern pada Pemerintah Daerah di Indonesia. Simposium Nasional Akuntansi XVIII Medan, 1-24. 